ISSN 1997-342X (Online), ISSN 1991-8631 (Print)

Original Paper http://ajol.info/index.php/ijbcs http://indexmedicus.afro.who.int

\title{
Determination of sexual dimorphism of African snakehead (Parachanna obscura): morphometric and meristic parameters, weight-length relationship and condition factor
}

\author{
D.S.J.V. VODOUNNOU ${ }^{1 *}$, D.N.S. KPOGUE ${ }^{2}$, Y. AKPO ${ }^{3}$, M. LAGNIKA ${ }^{4}$ and \\ E.D. FIOGBE ${ }^{1}$ \\ ${ }^{I}$ UAC University of Abomey-Calavi, FAST Faculty of Sciences and Techniques, \\ LRZH Laboratory of Research in the Wetlands 01 BP 526 Cotonou, Bénin. \\ ${ }^{2}$ UAK Agricultural University of Ketou, BP 43 Kétou, Bénin. \\ ${ }^{3}$ UP University of Parakou, FA Faculty of Agronomy, LESPA Laboratory of Ecology, \\ Health and Animals Production BP 123 Parakou, Bénin. \\ ${ }^{4}$ UAC University of Abomey-Calavi, FAST Faculty of Sciences and Techniques, \\ Zoology 01 BP 526 Cotonou, Bénin. \\ *Correspondence author; E-mail: justeking@yahoo.fr
}

\begin{abstract}
Artificial reproduction of fishes requires knowledge of their sexual dimorphism. African snakehead, Parachanna obscura, sexual dimorphism determination is difficult trough urogenital orifice examination. The aim of this study was to determine the sexual dimorphism of $P$. obscura using the parameters such as morphometric parameters, meristic parameters, weight-length relationship and condition factor. For the study, 30 specimens of $P$. obscura were collected from a swamp in Sakete a southeastern district of Benin. The fish weighed between $117 \mathrm{~g}$ and $251 \mathrm{~g}$ and their length were between $24.40 \mathrm{~cm}$ and $32.20 \mathrm{~cm}$. At the end of this study, the different fins ray number were not significantly different $(\mathrm{P}>0.05)$. There was no significant difference among male and female fish $(\mathrm{P}>0.05)$ in total length, standard length, head length, snout length, snout width, head circumference and body circumference. Tail length had a significantly difference between male and female $(\mathrm{P}<0.05)$. The weight-length relationship indicated an allometric growth for the males and an isometric growth for the females. Significant difference was observed between male and female in condition factor $(\mathrm{P}<0.05)$. The male condition factor was the double of female condition factor. Condition factor, tail length and weight-length can be used for $P$. obscura sexual dimorphism determination.
\end{abstract}

(C) 2017 International Formulae Group. All rights reserved.

Keywords: Parachanna obscura, sexual dimorphism, condition factor, weight-length relationship.

\section{INTRODUCTION}

Reproduction is essential for species conservation (Niass and Fall, 2015). In aquaculture, the supply of the seed must be assured for economic development of this sector (Ravindranath, 1988; Sirima et al.,
2009; Greiner and Gregg, 2010; Ibrahim and Nagar, 2010; Ouedraogo et al., 2015). Only natural propagation of some fish can't assure a breeding in captivity (Marimuthu et al., 2001; Mylonas et al., 2010). The control of artificial fish propagation is essential to promote 
aquaculture (Brzuska, 2004; De Lapeyre et al., 2010; Kamelan et al., 2013; Azrita et al., 2015). The artificial fish propagation necessitated a control of some parameters included sexual dimorphism (Makmur et al., 2003; Bijaksana et al., 2015). Some Channidae fish are difficult sexually to distinguish. Channidae fish is known as snakeheads, murrels or serpent-headed fish (Kumar et al., 2011; Kumar et al., 2012). They are fishes living in freshwater, having accessory respiratory organ to utilize atmospheric air for respiration that enables them to thrive in oxygen depleted waters and they are native to Asia and Africa (Qin and Fast, 1998; Ali, 1999; Kumar et al., 2012). They have a large mouth and sharp teeth with a long, cylindrical body with marks on the flank. Snakeheads have enlarged scales on the top of their heads and their eyes are located far forward on their head, similar to the scale patterns and eye positions of snakes (Courtenay and William, 2004). The feeding and habitat depend on life stages; juveniles eat zooplankton, insect larvae, the young of other fishes and small crustaceans and the adults, become voracious predators. Size and color patterns vary among 30 recognized species (Kumar et al., 2012).

The African Channidae is known as genus Parachanna with only three species (Parachanna africana, Parachanna insignis and Parachanna obscura) and are restricted to Central and West Africa (Kumar et al., 2012). Parachanna obscura is found in Benin a West African country. African Snakeheads, $P$. obscura flesh is very appreciated by African consumers. It has a high economic value for African aquaculture, and a better growth rate ( $2 \mathrm{~g}$ /day), few bones, and tasty flesh, accepts high stocking density and can use the atmospheric oxygen for respiration (Micha, 1974; Victor and Akpocha, 1992; Bolaji et al., 2011). Dietary protein requirement, feeding rate requirement, optimum stocking density of $P$. obscura were previously studied (Kpogue and Fiogbe, 2012a, 2012b; Kpogue et al., 2013). Few information exist about the artificial propagation of this specie, except the study on Induced spawning of african snakehead fish (Agokei and Hart, 2010) and the one on some aspects of the reproductive biology of african Snakehead parachanna obscura in itu-cross river system (Isangedighi and Umoumoh, 2011). The male and female uro-genital opening of male are same. The aim of this study was to determine the sexual dimorphism of $P$. obscura by using the parameters such as the morphometric and meristic parameters, weight-length relationship and condition factor.

\section{MATERIALS AND METHODS Specimen collection}

A total of 30 specimens of $P$. obscura were collected from a swamp in Takon, a Sakete district (Southeast Benin). specimens collection was carried out in rainy season with water temperature of $26.6^{\circ} \mathrm{C}, \mathrm{pH}: 6.4$ and dissolved oxygen $2.3 \mathrm{mg} / \mathrm{L}$. Collected fish specimens weight was $117 \mathrm{~g}$ and $251 \mathrm{~g}$. After the transfer of specimens in the Wetland Research Laboratory of Abomey-Calavi University, the fish specimens dissection was made to separate the male from the female. The alcohol of $96^{\circ}$ was used to keep the specimen.

\section{Moderate parameters}

According to the sex, the parameters such as:

Total Weight (TW),

Total Length (TL): Distance from the tip of the mouth to the extended tip of the caudal fin in $\mathrm{cm}$

Standard Length (SL): Distance from the tip of the mouth to the caudal peduncle in $\mathrm{cm}$

Tail Length (TaL): Distance from the tip of the caudal peduncle to the extended tip of the caudal fin in $\mathrm{cm}$

Head Length (HL): Distance from the tip of the mouth to the extended tip of the occiput in $\mathrm{cm}$

Snout Length (SL): Distance from the tip of the mouth to the former edge of the eye in $\mathrm{cm}$

Snout Width (SW): Distance between both ocular lobes in $\mathrm{cm}$

Head Circumference (HC): Circumference of head on a level with pectoral fins in $\mathrm{cm}$ 
Body Circumference (BC): Circumference of body on a level with orifice urogenital in $\mathrm{cm}$

Flank Number Task (FNT): Number of task on one flank

Scale Number of Lateral Line (SNLL): Number of scale on lateral line on one flank

Anal Number Ray (ANR): Number of ray on a level with anal fin

Dorsal Number Ray (DNR): Number of ray on a level with dorsal fin

Tail Number Ray (TNR): Number of ray on a level with tail fin

Pelvic number Ray (PnR): Number of ray on a level with one pelvic fin

Pectoral Number Ray (PNR): Number of ray on a level with one pectoral fin

were determined.

Calculated parameters and statistical analysis

Length-weight relationship was estimated using the equation: $\mathbf{T W}=\mathrm{a} \mathrm{TL}^{\mathrm{b}}$ (Ricker,1971)

The condition factor was determined by the formula: $\mathbf{K}=100 \mathrm{TW} / \mathrm{TL}^{\mathrm{b}}$

With:

$\mathbf{a}=$ intercept on $\mathrm{y}$-axis; $\mathbf{b}=$ an exponent between 2 and 4 (Bagenal and Tesch, 1978); $\mathbf{K}=$ condition factor (Tesch, 1971); TW $=$ Total Weight in $\mathbf{g}$; TL $=$ Total Length in $\mathrm{cm}$.

Data were analyzed with the STATVIEW version 5.01software. The data were analyzed using a one-way analysis of variance (ANOVA). Means were expressed as Means \pm SEM. Significant differences among means were determined using Fisher's test at $\mathrm{p}=0.05$ significance level. Relationship between weight and length were carried out using correlation and regression analyses.

\section{RESULTS}

Male and female urogenital opening

P.oscura is an African Channidae suitable for aquaculture because of good zootechnical performance, appreciated by African consumers and its high economic value. It has a large mouth and sharp teeth with a long cylindrical body with the marks on the flank (Figure 1). Sexual dimorphism based on urogenital orifice form is difficult (Sparre and Venema, 1979) because male and female urogenital orifice looks alike (Figures 2 and $3)$.

\section{Ray number of different fins}

Ray number of different fins was counted for sexual dimorphism determination (Table 1). Dorsal fin ray ranged between 41 and 42 in male, and was 41 in female. Anal fin ray ranged between 27 and 30 in male and female. Tail fin ray was 12 in male and female. Pelvic fin ray ranged between 5 and 6 in female and was 6 in male. Pectoral fin ray was 15 in male and female. The different fins ray number was not significantly different $(\mathrm{P}$ $>0.05$ ).

\section{P. obscura morphometric parameters}

Morphometric parameters such as: total length, standard length, tail length, head length, snout length, snout width, head circumference and body circumference were measured to determine a sexual dimorphism of $P$. obscura (Table 2). No significant difference was ever observed with these different morphometric parameters between male and female $(\mathrm{P}>0.05)$. Only the tail length was significantly different between male and female $(\mathrm{P}<0.05)$. The tale length can be used to distinguish $P$. obscura male from female.

\section{Weight, flank task and scale of lateral line}

Total weight, flank task number and scale number of lateral line were measured (Table 3). Total weight ranged between $124 \mathrm{~g}$ and $251 \mathrm{~g}$ in male and between $117 \mathrm{~g}$ and 236 $\mathrm{g}$ in female. Flank task number ranged between 6 and 8 in male and female. Scale number of lateral line ranged between 67 and 70 in male and between 66 and 70 in female. No significant difference was observed between male and female with these parameters $(\mathrm{P}>0.05)$.

Weight- length relationship for male 
Weight- Length relationship was determined by the following regression equations:

Male: $\mathrm{TW}=0.0197 \mathrm{TL}^{2.7422}$ with $\mathrm{r}^{2}=0.8366$ (Figure 4). Regression coefficient in the male was different from 3 (Table 4). The male had an allometric growth with more growth in length than in weight (Figure 4). A correlation exists between the total weight and the total length for the square of the correlation coefficient was superior to $0.6\left(\mathrm{r}^{2}>0.6\right)$ (Table 4).

\section{Weight- length relationship for female} Female: $\mathrm{TW}=0.0087 \mathrm{TL}^{3.0128}$ with $\mathrm{r}^{2}=$ 0.8558 (Figure 5). Regression coefficient for the female was not different from 3 (Table 4).
The female had isometric growth (Figure 5). Correlation exists between the total weight and total length because the correlation coefficient was superior to $0.6\left(\mathrm{r}^{2}>0.6\right)$ (Table 4).

\section{Condition factor}

Condition factor varied according to the sex (Figure 6). Condition factor ranged between 1.68 and $2.4(1.99 \pm 0.18)$ in male and varied from 0.78 to $0.97(0.88 \pm 0.06)$ in female. Significant difference was observed between male and female $(\mathrm{P}<0.05)$. Condition factor can be used to determine sexual dimorphism in P. obscura.

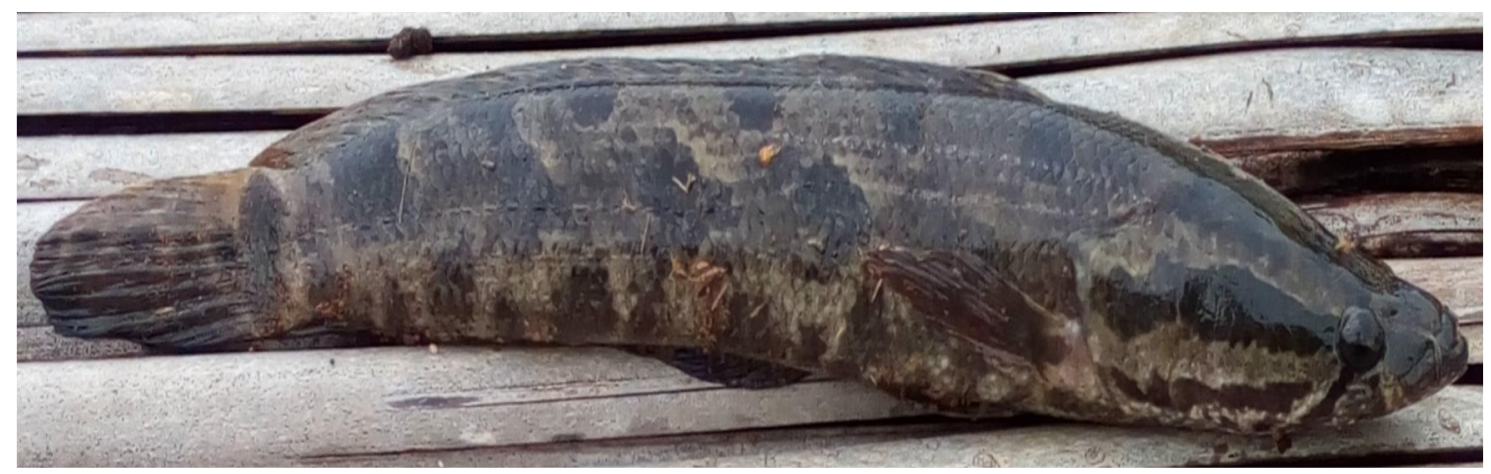

Figure 1: specimen of P.obscura.

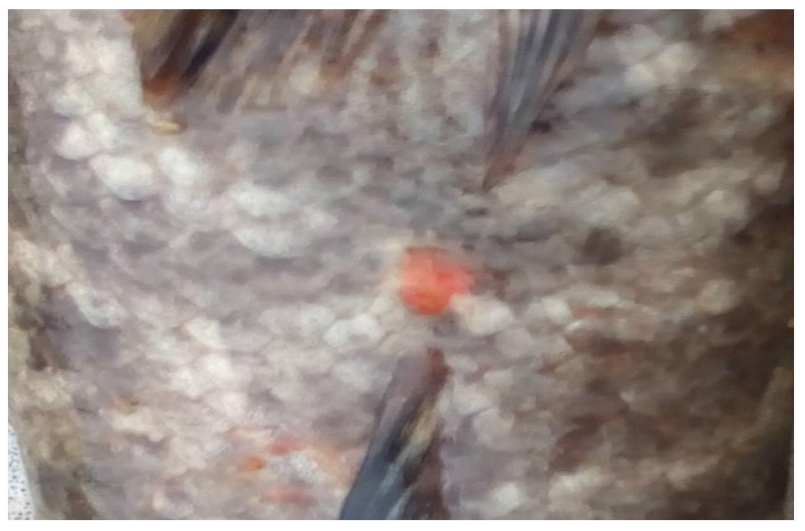

Figure 2: Orifice urogenital male of P. obscura 


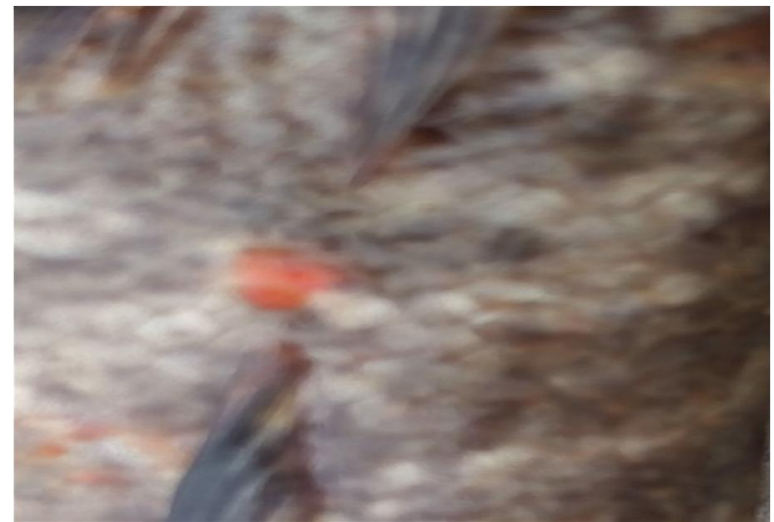

Figure 3: Orifice urogenital female of P. obscura.

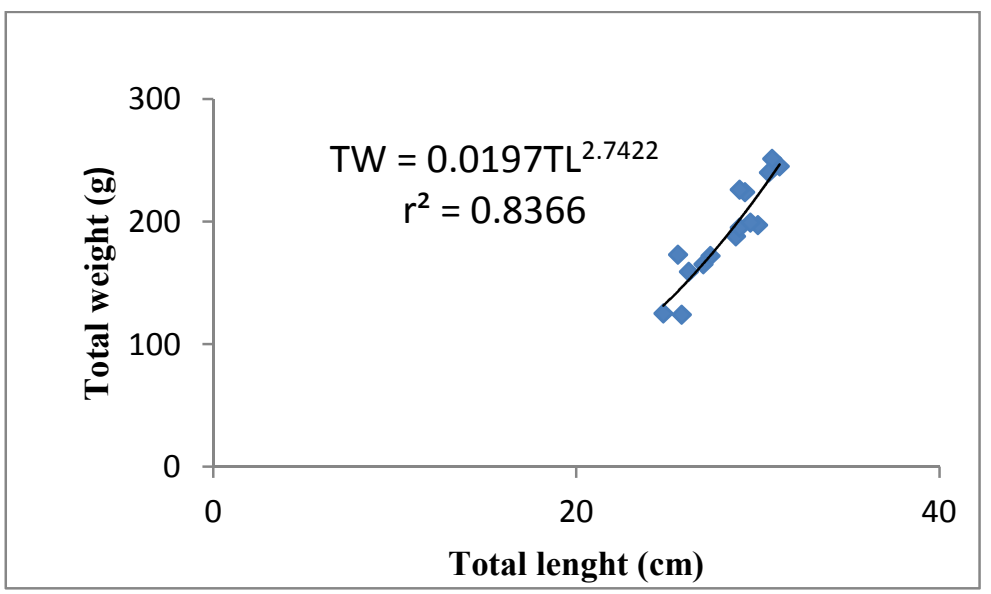

Figure 4: Weight- length relationship of male.

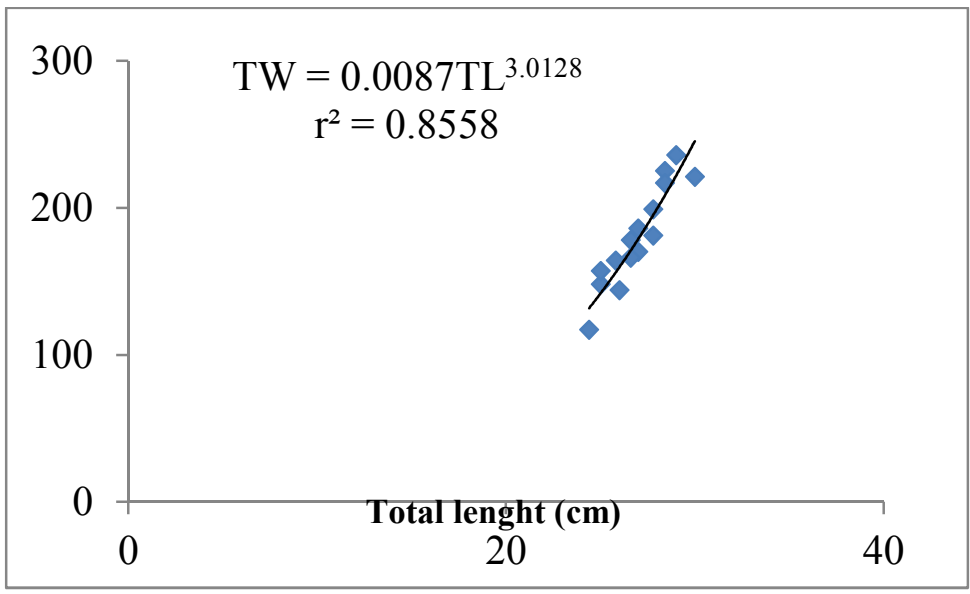

Figure 5: Weight- length relationship of female. 


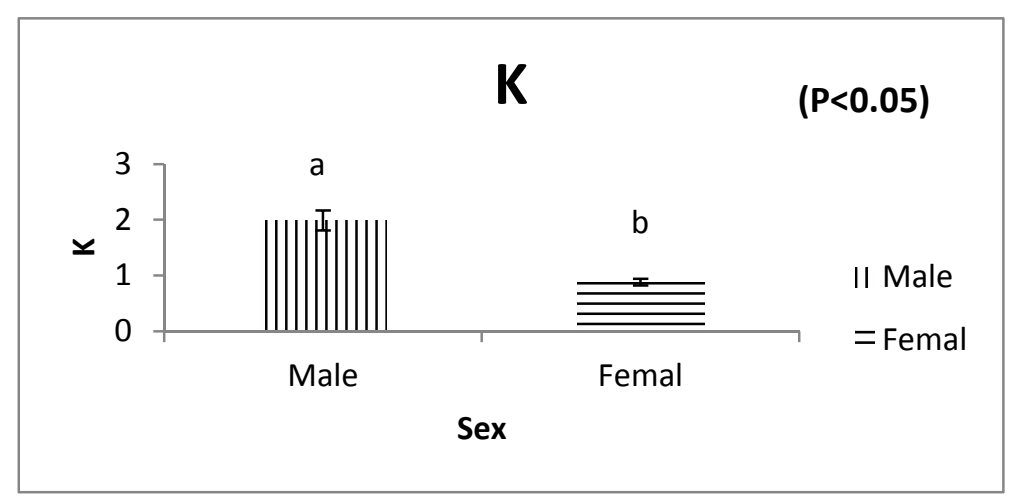

Figure 6: Condition factor.

Table 1: Ray number of different fins.

\begin{tabular}{|c|c|c|c|c|c|c|}
\hline Parameters & Sex & Number & Min & Max & Mean \pm SD & $\mathbf{P}$ \\
\hline \multirow{2}{*}{ Anal Ray Number } & $\hat{\sigma}$ & 15 & 27.00 & 30.00 & $28.60 \pm 0.99$ & \multirow{2}{*}{$(\mathrm{P}>0.05)$} \\
\hline & q & 15 & 27.00 & 30.00 & $28.66 \pm 0.98$ & \\
\hline \multirow{2}{*}{ Dorsal Ray Number } & $\hat{0}$ & 15 & 41.00 & 42.00 & $41.06 \pm 0.25$ & \multirow{2}{*}{$(\mathrm{P}>0.05)$} \\
\hline & o & 15 & 41.00 & 41.00 & $41.00 \pm 0.00$ & \\
\hline \multirow{2}{*}{ Tail Ray Number } & $\hat{\sigma}$ & 15 & 12.00 & 12.00 & $12.00 \pm 0.00$ & \multirow{2}{*}{$(\mathrm{P}>0.05)$} \\
\hline & q & 15 & 12.00 & 12.00 & $12.07 \pm 0.00$ & \\
\hline \multirow{2}{*}{ Pelvic Ray number } & $\hat{\sigma}$ & 15 & 6.00 & 6.00 & $6.00 \pm 0.00$ & \multirow{2}{*}{$(\mathrm{P}>0.05)$} \\
\hline & q & 15 & 5.00 & 6.00 & $5.87 \pm 0.35$ & \\
\hline \multirow{2}{*}{ Pectoral Ray Number } & $\hat{o}$ & 15 & 15.00 & 15.00 & $15.00 \pm 0.00$ & \multirow{2}{*}{$(\mathrm{P}>0.05)$} \\
\hline & 우 & 15 & 15.00 & 15.00 & $15.00 \pm 0.00$ & \\
\hline
\end{tabular}

Table 2: P. obscura morphometric parameters measured.

\begin{tabular}{|c|c|c|c|c|c|c|}
\hline Parameters & Sex & Number & Minimum & Maximum & Mean \pm SD & $\mathbf{P}$ \\
\hline \multirow{2}{*}{ Total Length } & $0^{1}$ & 15 & 24.80 & 32.20 & $28.34 \pm 2.07$ & \multirow{2}{*}{$(\mathrm{P}>0.05)$} \\
\hline & $q$ & 15 & 24.40 & 30.00 & $26.99 \pm 1.60$ & \\
\hline \multirow{2}{*}{ Standard Length } & $\hat{0}$ & 15 & 21.40 & 27.00 & $24.94 \pm 3.68$ & \multirow{2}{*}{$(\mathrm{P}>0.05)$} \\
\hline & q & 15 & 20.50 & 26.40 & $23.26 \pm 1.46$ & \\
\hline \multirow{2}{*}{ Tail Length } & $\hat{\sigma}$ & 15 & 3.40 & 5.80 & $4.17 \pm 0.63$ & \multirow{2}{*}{$(\mathrm{P}<0.05)$} \\
\hline & 우 & 15 & 2.80 & 4.40 & $3.72 \pm 0.44$ & \\
\hline \multirow{2}{*}{ Head Length } & $\hat{0}$ & 15 & 6.00 & 8.00 & $7.07 \pm 0.66$ & \multirow[t]{2}{*}{$(\mathrm{P}>0.05)$} \\
\hline & q & 15 & 6.00 & 7.50 & $6.73 \pm 0.40$ & \\
\hline \multirow{2}{*}{ Snout Length } & $\hat{\sigma}$ & 15 & 1.50 & 2.00 & $1.81 \pm 0.20$ & \multirow{2}{*}{$(\mathrm{P}>0.05)$} \\
\hline & q & 15 & 1.40 & 2.00 & $1.73 \pm 0.16$ & \\
\hline \multirow{2}{*}{ Snout Width } & $\hat{0}$ & 15 & 1.40 & 2.60 & $2.03 \pm 0.35$ & \multirow{2}{*}{$(\mathrm{P}>0.05)$} \\
\hline & q & 15 & 1.50 & 2.60 & $1.92 \pm 0.30$ & \\
\hline \multirow{2}{*}{ Head Circumference } & 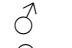 & 15 & 10.00 & 13.50 & $12.06 \pm 1.03$ & \multirow{2}{*}{$(\mathrm{P}>0.05)$} \\
\hline & q & 15 & 10.50 & 13.00 & $11.95 \pm 0.79$ & \\
\hline \multirow{2}{*}{ Body Circumference } & $\hat{0}$ & 15 & 9.80 & 13.00 & $11.67 \pm 0.92$ & \multirow{2}{*}{$(\mathrm{P}>0.05)$} \\
\hline & q & 15 & 9.90 & 13.80 & $11.86 \pm 1.08$ & \\
\hline
\end{tabular}


Table 3: Weight, flank task and scale of lateral line of P. obscura.

\begin{tabular}{lcccccc}
\hline Parameters & Sex & Number & Minimum & Maximum & Mean \pm SD & P \\
\hline \multirow{2}{*}{ Total Weight(g) } & $\hat{0}$ & 15 & 124.00 & 251.00 & $192.20 \pm 40.15$ & $(\mathrm{P}>0.05)$ \\
& + & 15 & 117.00 & 236.00 & $180.60 \pm 33.78$ & \\
Flank Number Task & 0 & 15 & 6.00 & 8.00 & $7.20 \pm 0.56$ & $(\mathrm{P}>0.05)$ \\
Scale Number of Lateral & + & 15 & 6.00 & 8.00 & $7.20 \pm 0.86$ & \\
Line & $\delta$ & 15 & 67.00 & 70.00 & $68.47 \pm 0.91$ & $(\mathrm{P}>0.05)$ \\
\hline
\end{tabular}

Table 4: Parameters of weight- length relationship of P. obscura.

\begin{tabular}{lccc}
\hline Sex & $\mathbf{a}$ & $\mathbf{b}$ & $\mathbf{r}^{2}$ \\
Male & 0.02 & 2.74 & 0.84 \\
Female & 0.01 & 3.01 & 0.85 \\
\hline \multicolumn{2}{l}{ With: $\mathbf{a}=$ intercept on y-axis; $\mathbf{b}=$ an exponent between 2 and 4}
\end{tabular}

\section{DISCUSSION}

Sexual dimorphism of $P$. obscura is not an easy task with urogenital orifice consideration. Meanwhile, other parameters such as: morphometric parameters, meristic parameters, coat, weight-length relationship and condition factor can be used for sexual dimorphism determination. Ray number of different fins like, anal fin, tail fin, pelvic fin and pectoral fin were not significantly different in male and female. The dorsal fin ray number ranged between 41 and 42 in male, and was 41 in female. This result agreed with the study of Leveque et al. (1990a) on description of this species in the fresh and brackish fish water of West Africa where the dorsal fin ray ranged between 39 and 45 . The same study showed that the anal fin ray (2632) ranged between 27 and 30 in male and female. Scale number of lateral line ranged between 67 and 70 in male and 66 and 70 in female. This observation agreed with the study of Kumar et al. (2012) on sneakhead fishes fact sheets where the Scale number of lateral line ranged between 65 and 78. The flank task number ranged between 6 and 8 in male and female agreed with the study of Leveque et al. (1990b) on description of this species in the fresh and brackish fish water of West Africa where the flank task number ranged between 5 and 8 . The flank task number in both studies does not exceed 8 .

The morphometric parameters, total length, standard length, head length, snout length, snout width, head circumference and body circumference were not significantly different between male and female. The maximum total length of this fish reported by Bonou and Teugels (1985) on systematic revision of Parachanna genus was $41 \mathrm{~cm}$ and $35 \mathrm{~cm}$ on guide to the fishes of the river nile in the republic of the Sudan (Bailey, 1994). Those lengths are larger than the largest specimen $(32.20 \mathrm{~cm})$ observed in this study. 
But the tail length can be used to determine the sexual dimorphism of $P$. obscura because a significant difference exists between male and female. Tail length of male is $4.17 \pm 0.63$ while the female's is $3.72 \pm 0.44$.

Significant difference was observed between male and female in condition factor. The male condition factor is the double of female condition factor. The condition factor value observed in the current study was lower compared to the one obtained by Olurin and Savage (2011) on $P$. obscura male reproductive biology in Southwestern Nigeria $(59.49 \pm 9.52)$. Female condition factor in this study $0.88 \pm 0.06$ is also lower than the female condition factor obtained by Olurin and Savage (2011) $(1.357 \pm 0.4305)$. In the study of these authors, condition factor of the male was forty four times that of the female. In both studies, significant differences were observed between male and female in condition factor parameter. This parameter can be used to determine a sexual dimorphism in P. obscura.

Female specimens of $P$. obscura in this study were isometric growth because the regression coefficient was not significantly different from $3(b=3.01)$. This study agreed with that of Olurin and Savage (2011) on $P$. obscura reproductive biology in Southwestern Nigeria and disagreed with the study of Codjo (2012) on biology and ecology characterization of $P$. obscura in South of Benin where the regression coefficient were 2.74 and 2.66 in two regions without sexual difference. The regression coefficient of female in this study was different from male regression coefficient. Male specimens were allometric growth because the regression coefficient was significantly different from 3 $(b=2.74)$. This result corroborated with the study of Olurin and Savage (2011) P. obscura reproductive biology in Southwestern Nigeria where the regression coefficient of male was 1.77. This study shows that $p$. obscura male length was larger than the female specimen length. The study prove that weight-length relationship can be used to determine a sexual dimorphism in P. obscura.

\section{Conclusion}

African snakeheads, Parachanna obscura has a high economic value in african aquaculture, but the similar form of male and female urogenital orifice its make the artificial reproduction of this species difficult. This study tried to determine the sexual dimorphism by using other parameters such as: morphometric parameters, weight-length relationship and condition factor. The current study proved that tail length, weight-length relationship and condition factor can be used to distinguish P.obscura male and female.

\section{COMPETING INTERESTS}

The authors declare that there is no conflict of interests.

\section{AUTHORS' CONTRIBUTIONS}

All authors, DSJVV, DNSK, YA, ML and EDF have made adequate effort on all parts of the work necessary for the development of this manuscript according to his/her expertise. All authors read and approved the final manuscript.

\section{ACKNOWLEDGEMENTS}

We thank the authors of this study, the Laboratory of Research on Wetland of Abomey-calavi University and the Ministry of High Education and Scientific Research of 
Benin Republic which provided a $\mathrm{PhD}$ grant to D.S. Juste Vital Vodounnou.

\section{REFERENCES}

Agokei OE, Hart AI. 2010. Induced spawning of the African snakehead fish. Poster presented in World Aquaculture Society meetings. AQ 2010. 1087.

Ali AB. 1999. Aspects of the reproductive biology of female snakehead (Channa striata Bloch) obtained from irrigated rice agroecosystem, Malaysia. Hydrobiologia, 411: 71-77.

Azrita, Yuneidi B. Hafrijal S. 2015. Preliminary study on domestication of Bluespotted Snakehead (Channa Lucius, Channidae) in concrete tank. $J$ Aquac Res Development, 6: 2 http://dx.doi. org/10.4172/2155-9546.1000309

Bagenal TB, Tesch FW. 1978. Age and growth. In Methods of Assessment of Fish Production of Commercially Important Marine Fishes. Ed. Bagenal T., Oxford Blackwell Scientific: Oxford; 101-136.

Bailey RG. 1994. Guide to the fishes of the River Nile in the republic of the Sudan. J. Nat. Hist., 28: 937-970.

Bijaksana U, Hidayaturrahmah, Sari DDK. 2015. Re-stocking' model of snakehead farming, Channa striata blkr in the swamp bangkau of South Kalimantan Province. Global Journal of Fisheries and Aquaculture, 3(2): 198-204.

Bolaji BB, Mfon TU, Utibe DI. 2011. Preliminary study on the aspects of the biology of snakehead fish Parachanna obscura (Gunther) in a Nigerian wetland. African Journal of Food and Agriculture Nutrition Development, 11(2): 47084717.
Bonou CA, Teugels GG. 1985. Révision systématique $\mathrm{du}$ genre Parachanna (Teugels \& Daget, 1984) (Pisces: Channidae). Rev. Hydro. Tropi., 18: 267 -280 .

Brzuska E. 2004. Artificial propagation of African catfish (Clarias gariepinus): the application of a single dose of pellets containing D-Ala6 Pro9NEt-mGnRH and dopamine inhibitor metoclopramide. Czech J. Anim. Sci., 49(7): 289-296.

Codjo L. 2012. Biology and ecology characterization of Parachanna obscura in Oueme valley in south Benin. Msc thesis / department of sciences and techniques animals/Faculty of agronomy/University of parakou, 52p.

Courtenay WR, Williams JD. 2004. Snakeheads (Pisces, Channidae). A Biological Synopsis and Risk Assessment: USGS Circular 1251, 143 p.

De Lapeyre BA, Muller-Belecke A, HorstgenSehwark G. 2010. Increased spawning activity of female Nile tilapia (Oreochromis niloticus) (L.) after stocking density and photoperiod manipulation. Aquacult. Res., 41(10): 561-567.

Greiner R, Gregg D. 2010. Considering recreational catch and harvest in fisheries management at the bio-regional scale. Fish. Manage. Ecol., 17(4): 336-345.

Ibrahim N, Nagar GE. 2010. Water quality, fish production and economics of Nile tilapia, Oreochromis niloticus and African catfish, Clarias gariepinus, monoculture and polyculture. J. World Aquacult. Soc., 41(4): 574-582.

Isangedighi I A, Umoumoh OE. 2011. Some aspects of the reproductive biology of 
african Snakehead parachanna obscura in itu-cross river system. Nigerian Journal of Agriculture, Food and Environment, 7(4):19-30.

Kamelan TM, Berté S, N'Zi GK, Bamba M, Bi GG, Kouamélan EP. 2013. Peuplement ichtyologique du complexe Brimé-Méné-Nounoua, Côte d'Ivoire (Afrique de l'Ouest). International Journal of Biological and Chemical Sciences, 7(6): 2248-2263.

Kpogue DNS, Ayanou GA, Toko II, Mensah GA, Fiogbe ED. 2013. Influence of dietary protein levels on growth, feed utilization and carcass composition of snakehead, Parachanna obscura (Günther, 1861) fingerlings. International Journal of Fisheries and Aquaculture, 5(5): 71-77.

Kpogue DNS, Fiogbe ED. 2012a. Feeding rate requirements for Parachanna obscura fry reared under controlled environmental conditions. Journal of Applied Biosciences, 55: 3962- 3972.

Kpogue DNS, Fiogbe ED. 2012b. Optimum stocking density for Parachanna obscura larvae fed at its optimum ration. International Journal of Biological and Chemical Sciences, 6(3): 1293-1302.

Kumar K, Kumar R, Saurabh S, Sahoo M, Mohanty AK, Lalrinsanga PL, Mohanty UL, Sahu AK, Jayasankar P. 2012. Snakehead Fishes Fact Sheets. Central Institute of Fresh Water Aquaculture, Kausalyaganga, Bhubaneswar- 751 002: Odisha, India.

Kumar K, Eknath AE, Sahu AK, Mohanty UL, Kumar R, Sahoo Noor J. 2011. Snakeheads: Challenging fish for diversification of fish farming. Fishing Chimes, 31(1):110-113.
Leveque C, Paugy D, Teugels GG. 1990a. The Fresh and Brackish Water Fishes of West Africa (Tome 1). ORSTOM/MRAC; p 384.

Leveque C, Paugy D, Teugels GG. 1990b. The Fresh and Brackish Water Fishes of West Africa (Tome 2). ORSTOM/MRAC; p 517.

Makmur S, Rahardjo MF, Sukimin S. 2003. Biology reproductive of Channa striata Bloch in floodplain Musi River South Sumatra. J Iktiologi Indonesia, 3: 57-62.

Marimuthu K, Haniffa MA, Muruganandam M, Arockia Raj AJ. 2001. Low cost murrel seed production. Technique for fish farmers. Naga, 24(1-2): 21-22.

Micha JC. 1974. Fish populations study of Ubangui river: trying local wild species for fish culture. Aquaculture; 4: 85-87.

Mylonas CC, Fostier A, Zanny S. 2010. Broodstock management and hormonal manipulations of fish reproduction. Gen. Comp. Endrocrinol, 165(3): 516-534.

Niass F, Fall S, 2015. Reproduction and larval rearing of the fresh water prawn, Macrobrachium vollenhovenii in Senegal. International Journal of Biological and Chemical Sciences, 9(6): 2523-2534.

Olurin KB, Savage OD. 2011. Reproductive biology, length-weight relationship and condition factor of the African snake head, Parachanna obscura, from River Oshun, South-west Nigeria. International Journal of Fisheries and Aquaculture, 3(8): 146-150.

Ouedraogo R, Soara AE, Zerbo H 2015. Caractérisation du peuplement piscicole du réservoir de Boalin, Ziniaré (Burkina Faso) deux décennies après l'introduction de Heterotis niloticus. 
International Journal of Biological and Chemical Sciences, 9(5): 2488-2499.

Qin JG, Fast AW. 1998. Effects of temperature, size and density on culture performance of snakehead Channa striatus (Bloch), fed formulated feed. Aquacult. Res., 29(4); 299-303.

Ravindranath K. 1988. Propagation of the commercially important air breathing fish channa striata (bloch) in farm ponds. Indian J. Fish., 35(4): 330-332

Ricker WE.1971. Linear regressions in fisheries research. J. Fish. Res. Board. Canc., 30: 409 - 434.

Sirima O, Toguyeni A, Kaboré-Zoungrana CY. 2009. Faune piscicole du bassin de la Comoé et paramètres de croissance de quelques espèces d'intérêt économique. International Journal of Biological and Chemical Sciences, 3(1): 95-106.

Sparre P, Venema SC. 1979. Introduction to tropical fish stock assessment. Part 1: Nabyak-FAO fish technic. 306: 1-376.

Tesch W. 1971. Age and Growth. International Biological Programme: Oxford and Edinburgh; 97-130.

Victor R, Akpocha BO. 1992. The biology of Snakehead, Channa obscura (Gunther), in a Nigerian pond under monoculture. Aquaculture, 101: 17-24. 